\title{
«Невидимі» бар'єри соціальної нерівності: передумови відтворення у дошкільній і початковій освіті
}

Нечітайло І. С., Мінко А. В., Харківський гуманітарний університет «Народна українська академія»

Статтю присвячено розгляду бар'єрів соціальної нерівності, що відтворюються в освіті, зокрема на iï початкових рівнях. Встановлено, що результати більшості сучасних соціологічних досліджень свідчать про те, що успіхи в освіті та соціальний статус, що досягається через деякий час після закінчення навчання, залежать від соціального походження індивіда. Зауважується, що така залежність свідчить про недієвість легальних механізмів соціальної мобільності, зокрема тих, що закладені в основу функціонування інституту освіти. Оцінено вплив факторів нерівності, що $є$ мало вивченими в соціології. 3 опорою на праці зарубіжних соціологів, виявлено «бар'єри», що мають місце в системі освіти, сприяють відтворенню соціальної нерівності і перешкоджають вертикальній соціальній мобільності. Особливу увагу приділено науковому осмисленню одного з них, який пов'язаний із відмінностями у мовних і когнітивних кодах, носіями яких є діти - вихідці з різних соціальних прошарків. Надаються авторські тлумачення термінів «мовний код» $\mathrm{i}$ «когнітивний код». Наводяться результати досліджень, проведених за участю авторів у 2013-2015 роках, що підтверджують наявність і розкривають механізм дії зазначеного бар'єру. За результатами досліджень доведено, що ступінь розвиненості когнітивних кодів, хоча і залежить від фактору соціального походження, зокрема від роду професійної діяльності матері як найважливішого агенту первинної соціалізації, все ж таки стиль роботи педагога значною мірою впливає на розвиток когнітивних кодів. Робиться заключний висновок про те, що дотримання вчителями демократичних засад спілкування і діалогічності освітнього дискурсу, спрямованість викладацьких методик, перш за все, на когнітивний розвиток учнів (а не на завантаження їх пам'яті інформацією) дозволить зняти один із фундаментальних бар'єрів нерівності в освіті, що закладається ще на перших освітніх сходинах - на рівні загальної дошкільної та початкової шкільної освіти.

Ключові слова: код когнітивний; код мовний; інститут освіти; фактори соціальної нерівності; соиіальний прошарок; соиіально значущі ресурси; соџіальні шанси; педагог

\section{«Invisible» barriers to social inequality: the preconditions for reproduction in preschool and primary education}

\section{Nechitailo I. S., Minko A. V., Kharkiv Humanitarian University «People's Ukrainian Academy»}

The article is devoted to the consideration of barriers to social inequality, which are reproduced in education in particular at its initial levels. Emphasized that the results of the majority of modern sociological studies indicate that the successes in education and the social status achieved after a certain time after graduation depend on the social origin of the individual. Such dependence testifies to the ineffectiveness of legal mechanisms of social mobility, including those that are laid in the basis of the functioning of the institution of education. The influence of inequality factors poorly studied in sociology is estimated. With the support of the works of foreign sociologists, «barriers» that take place in the education system, promote the reproduction of social inequalities, and impede vertical social mobility have been identified. Particular attention is paid to the scientific comprehension of one of such barriers, connected with differences in linguistic and cognitive codes, whose carriers are children from different social strata. Author's interpretation of the terms «language code» and «cognitive code» is provided. The results of studies carried out with the authors' participation confirming the presence and revealing mechanism of the action of the indicated barrier are presented. The results of researches conducted with the participation of authors in 2013-2015 are presented. These results confirm the existence and revealing the mechanism of action of he barrier referred to above. Based on the results of researches, it is proved that the degree of development of cognitive codes, although it depends on the factor of social origin, in particular, on kind of professional activity of mother as the most important agent of primary socialization, nevertheless the teacher's work style largely influences the development of cognitive codes. A final conclusion is that the teachers' adherence to democratic principles of dialogue and dialogic nature of educational discourse, an orientation of teaching methods, first of all, on the cognitive development of students (rather than loading their memory with information) will allow one of the fundamental barriers to inequality in education to be laid at the first educational levels - general preschool and primary school education.

Keywords: cognitive code; language code; education institution; social inequality factors; social stratum; socially significant resources; social chances; teacher 


\title{
«Невидимые» барьеры социального неравенства: предпосылки воспроизводства в дошкольном и начальном образовании
}

\author{
Нечитайло И. С., Минко А. В., Харьковский гуманитарный университет «Народная украинская \\ академия»
}

Статья посвящена рассмотрению барьеров социального неравенства, которые воспроизводятся в образовании, в частности на его начальных уровнях. Установлено, что результаты большинства современных социологических исследований свидетельствуют о том, что успехи в образовании и социальный статус, достигаемый по истечении определенного времени после окончания учебы, зависят от социального происхождения индивида. Отмечается, что такая зависимость свидетельствует о неэффективности легальных механизмов социальной мобильности, в том числе тех, которые заложены в основу функционирования института образования. Оценено влияние факторов неравенства, которые мало изучены в социологии. С опорой на труды зарубежных социологов, выявлены «барьеры», имеющие место в системе образования, способствующие воспроизводству социального неравенства и препятствующие вертикальной социальной мобильности. Особое внимание уделено научному осмыслению одного из таких барьеров, связанного с различиями в языковых и когнитивных кодах, носителями которых являются дети - выходцы из различных социальных слоев. Предоставляются авторские трактовки терминов «языковой код» и «когнитивный код». Приводятся результаты исследований, проведенных с участием авторов в 2013-2015 годах, подтверждающие наличие и раскрывают механизм действия указанного барьера. С опорой на результаты исследований доказано, что степень развитости когнитивных кодов, хотя и зависит от фактора социального происхождения, в частности, от рода профессиональной деятельности матери как важнейшего агента первичной социализации, все же, стиль работы педагога в значительной степени влияет на развитие когнитивных кодов. Делается заключительный вывод о том, что соблюдение учителями демократических принципов общения и диалогичности образовательного дискурса, направленность преподавательских методик, прежде всего, на когнитивное развитие учащихся (а не на загрузку их памяти информацией) позволит снять один из фундаментальных барьеров неравенства в образовании, который закладывается еще на первых образовательных ступенях - на уровне общего дошкольного и начального школьного образования.

Ключевые слова: код когнитивный; код языковой; институт образования; факторы социального неравенства; социальный слой; сочиильно значимые ресурсы; социальные шансы; педагог

\section{Постановка проблеми.}

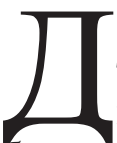
ослідження ролі освіти у процесах творення і відтворення соціальної нерівності має давню традицію, а проблематика соціальної нерівності $є$ ключовою для соціології. Будь-яка держава сучасного світу - це «суспільство нерівних». Власне, соціальна нерівність як така є цілком природньою, оскільки пов'язана з різними здібностями, посяганнями і прагненнями людей. Нерівність стає проблематичною для суспільства, такою, що породжує явні чи латентні соціальні конфлікти, потрясіння, девіації тощо, у ситуації недієвості так званих «соціальних ліфтів» як механізмів вертикальної соціальної мобільності, відсутності легальних шляхів отримання соціально значущих ресурсів. Одним із таких «ліфтів» $€$ інститут освіти. Утім, результати соціологічних досліджень, проведених в останні роки в Україні і в світі $[1 ; 2 ; 7 ; 8]$, свідчать про його недієвість.

Аналіз досліджень і публікацій.

У руслі зазначеної проблематики працювали такі класики соціологічної думки, як
К. Маркс, М. Вебер, П. Сорокін та ін. Значний внесок у іiі розвиток внесений сучасними західними соціологами і соціальними вченими, а саме: Б. Бернстайном, С. Боулзом, П. Бурдьє, Г. Гінтісом, Ф. Джексоном, Е. Кінгом, І. Іллічем, У. Кілпатриком, Г. Лоббаном, А. Макдугалом, П. Мехоні, Д. Спендером, П. Фрейре, Д. Т. Хансеном, Дж. Хенрі, М. Епплом та ін. На пострадянському просторі взаємозв'язок освіти 3 процесами соціальної, соціально-статусної, соціально-класової диференціації і нерівності досліджується С. Бродською, В. Добреньковим, Н. Коваліско, О. Куценко, С. Макеєвим, С. Оксамитною, О. Симончук та ін. [1;2; $4 ; 7 ; 8 ; 9]$.

Слід зазначити, що результати більшості проведених досліджень підтверджують наявність залежності від соціального походження успіхів в освіті та соціального статусу, що досягається через деякий час після закінчення навчання, однак не пояснюють на достатньому рівні причин такого взаємозв'язку.

Мета дослідження.

Виходячи із зазначеного, дана стаття має на меті виявлення передумов відтворення соціаль- 
ної нерівності, які не є очевидними, вкорінені в соціальний устрій інституту освіти і пов'язані зі специфікою інституціоналізованих відносин учасників освітнього процесу, зокрема, тих, хто навчає, і тих, хто навчається.

Виклад основного матеріалу.

Як відомо, соціальна нерівність - це неоднакове становище статусів у соціальному просторі, обумовлене низкою суб'єктивних (здатності індивідів виконувати ту чи іншу соціальну роль тощо) і об'єктивних (можливості, що надаються суспільством для досягнення того чи іншого положення в суспільстві) причин. Високо розвинені країни світу, які обрали для себе демократичний шлях, прагнуть нівелювати, знизити значущість об'єктивних причин і факторів соціальної нерівності, усунути соціальні бар'єри вертикальної соціальної мобільності, вирівняти шанси людей на досягнення високих, привілейованих або просто бажаних статусів, послабивши їх (шансів) залежність від соціального походження.

Освіта є тим соціальним інститутом, на який покладаються найбільші надії в цьому відношенні: саме освіта покликана виконувати функцію соціального ліфта, «вирівнювача» шансів. Власне, саме у цьому полягає одна 3 найголовніших функцій освіти як соціального інституту. Як пише відомий західний соціолог Е. Гідденс, теоретично перехід до практики загальної шкільної освіти в XX столітті був значним кроком до суспільства 3 рівними можливостями, навіть не дивлячись на те, що викликаний він виключно потребами економіки у кваліфікованих робітниках та інженерно-технічних фахівцях. Науково-технічна революція, інформатизація і автоматизація виробництва вимагали від організацій і підприємств підвищеної уваги до рівня підготовки їх працівників, в тому числі і на місця звичайних робітників. Тому полегшення доступності освіти для вихідців із різних верств населення було цілком природнім. Утім, на жаль, на практиці такий шлях не видався сприятливим для усунення бар'єрів соціальної нерівності. Більш того, ці бар'єри встановилися і почали функціонувати в самій системі освіти, а їх закладка відбувається ще у початковій школі - поділом учнів за соціальними ознаками [3, с. 341].

Законодавством більшості розвинених країн світу обов'язково забезпечується право кожного без виключення громадянина на освіту. Утім, дані сучасних соціологічних досліджень, що проводяться 3 метою діагностики соціальної нерівності, свідчать про наявність значних ресурсних розривів між нижчими і вищими соціальними прошарками, низькостатусними i високостатусними соціальними групами. Такі розриви свідчать про недієвість законів і встановлених державою соціальних ліфтів.

Про наявність таких розривів в українському соціумі і недієвість інституту освіти як соціального ліфту свідчать дослідження, проведені Інститутом соціології НАН України, про що пише в своїй статті український соціолог С. Оксамитна [7, с. 30]. Вона наводить цікаві дані, що свідчать про відтворення в освіті соціальної нерівності від покоління до покоління. У висновку статті дослідниця висуває припущення про існування в самому інституті освіти бар'єрів, які ускладнюють досягнення вихідцями 3 нижчих верств суспільства успіхів в освіті, що не дозволяє успішно закінчити навчальний заклад і стає перепоною для подальшого просування вгору за соціальною ієрархією.

Зарубіжні вчені О. Осипов і Н. Матвеєва в спільній науковій праці, присвяченій осмисленню і концептуалізації механізмів доступності освіти, досить повно описують так звані «бар'єри нерівності», що мають місце в освіті [9, с. 45]. Вчені відзначають, що найчастіше соціологи пояснюють причини неоднакових успіхів в освіті відмінностями потреб і поведінки соціальних груп у сфері освіти. Такі дослідження, безумовно, є цікавими, корисними, але не наближають до розуміння комплексу зв'язків між системою освіти і соціальною нерівністю, не наближають до пом'якшення умов, що перешкоджають рівному доступу до якісної освіти.

Досліджуючи проблеми соціального розшарування в освіті, вітчизняна соціологія в значній мірі спирається на зарубіжні розробки. Проблема відтворення нерівності через освіту знаходить відображення у специфічних теоріях культурного капіталу, репродукції, когнітивних і мовних кодів (Б. Бернстайн, П. Бурдьє, М. Еппл та ін.) $[1 ; 2 ; 10]$. Цінність наукового здобутку цих вчених полягає в тому, що вони зауважують на прихованих, неочевидних, таких, що мають місце всупереч законодавству механізмах соціального розшарування в освіті. Результатами власних досліджень вони підтверджують, що бар'єри доступності (якісної) освіти є непомітними для пересічного громадянина, невловимими для неповсякденно сприйняття, утім, вони існують, сприяючи відтворенню соціальної нерівності за ознакою соціального походження. Таке відтворення в громадській думці, в медій- 
ному і політичному дискурсі списується на рахунок самих «жертв» нерівності - їх нібито слабких здібностей, відсутності прагнення та / або бажання досягати більш високих соціальних позицій тощо.

О. Осипов і Н. Матвеєва виділяють наступні бар'єри нерівності в освіті [9, с. 47]: 1) трекінг (розведення учнів за здібностями); 2) комерціалізація освіти; специфіка відносин тих, хто навчає 3 тими, хто навчається; структура сім’ї учнів та іiі розмір; 3) ціннісне ставлення батьків до навчання їхніх дітей; 4) мовні здібності учнів, які зумовлюють їх навчальні успіхи.

Останній бар'єр особливо привернув нашу увагу з причини майже повної відсутності наукових досліджень, які б свідчили про його фактичну наявність. Одиничні камерні дослідження проводилися Б. Бернстайном і П. Бурдьє. Їх результати підтвердили, що вихідці з різних соціальних прошарків (соціально-класових груп) оперують специфічними когнітивними і мовними кодами, «налаштованими» або «неналаштованими» на складну кодову систему освіти. Детальному розгляду результатів цих досліджень присвячено низку наших наукових праць виданих раніше [4; 5, с. 301], отже не вважаємо за необхідне в даній статті повторювати відповідні положення і висновки. Утім, зауважимо, що різні соціальні (соціально-класові) групи використовують різні форми вживання мови, а мовні практики, поширені у цих групах, формують різні за складністю когнітивні коди. Мовні практики працівників фізичної праці та іiі різновидів відрізняються використанням коротких, простих, часто незакінчених речень 3 бідною синтаксичною структурою. Комунікація базується на простому принципі використання мови, в результаті чого формуються прості когнітивні коди. Мова працівників розумової (інтелектуальної) праці істотно відрізняється використанням більш довгих речень, які мають складну структуру. В основу їх комунікації покладений складний принцип використання мови, що сприяє формуванню складних когнітивних кодів [1, с. $85 ; 2$, c. 87]. Найбільш активне формування мовних i когнітивних здібностей ${ }^{1}$ відбувається у віці 5-6 років. Рівні когнітивного розвитку, лексичних навичок та готовності до навчання в цілому у дітей різного соціального походження суттєво відрізняються.
За прикладом досліджень, проведених цими вченими, із запозиченням їх дослідницької методології на кафедрі соціології Харківського гуманітарного університету «Народна українська академія» протягом 2013-2014 рр. реалізовувався проект під назвою «Освіта та коди нерівності» (керівник - д. с. н. Нечітайло I. С.).

Теоретично ми інтерпретуємо код як установку на смисли, на розуміння соціальної реальності, яка є латентною складовою соціальної дії. Розрізняємо когнітивні та мовні коди. Код когнітивний - логічна диспозиція, схильність до певних логічних висновків, представлена певним набором схем уяви та мислення, які є результатом практичного досвіду і формуються у процесі повсякденної взаємодії, в тому числі через оволодіння мовою. Код мовний - набір схем символічного вираження думок, тобто пов'язаних певним чином слів та інших символічних знаків. На емпіричному рівні когнітивні та мовні коди розрізняються за ступенем складності [6, с. 19].

В основу дослідження був покладений нетрадиційний для соціології метод - тест угруповання картинок, який дозволив виявити ступені розвиненості когнітивних та мовних кодів дітей, після чого дослідити їх залежність від рівня освіти і соціально-професійного статусу батьків. У якості об'єкта дослідження виступили вихованці підготовчих груп дитсадків і першокласники шкіл м. Харкова років $(\mathrm{n}=402)$. Результати цього дослідження також були описані нами у попередніх наукових працях [4; 5, с. 301], тому зауважимо лише на основному висновку, який $\epsilon$ важливим для подальших міркувань в межах цієї статті. Отже, факторний і кореляційний аналіз показали, що найбільш потужним за ступенем впливу на формування кодів $€$ фактор «сімейно-соціально-статусний», зокрема професія i освіта матері. Діти працівників розумової праці 3 вищою освітою частіше $є$ носіями складного коду і у зв'язку з цим показують кращі успіхи в освіті. Те ж саме стосується мовного коду. Окрім того, спираючись на отримані дані, нами було висунуто припущення стосовно трансформації кодів: їх ускладнення і розвиток, як і гальмування цих процесів, значною мірою залежать від стилю роботи, характеру взаємодії педагога зі своїми вихованцями, від того, наскільки жорстким (суворим) або лояльним й демократичним він є. Зауважимо, що характер взаємодії, хоча

1 Зокрема, маються на увазі здібності узагальнення, абстрагування та класифікації об’ єктів реальності, які у значній мірі визначають подальші успіхи когнітивного розвитку, готовність до здійснення більш складних розумових процедур, а також здібності лаконічно й аргументовано висловлю свою думку тощо 
і залежить від особистісних якостей вчителя (викладача), все ж таки у більшості випадків відповідає загальним нормам навчальної установи, в якій він працює, а отже несе на собі відбиток інституціоналізованих відносин ${ }^{2}$, що в ній склалися.

Оскільки останній висновок нами було сформульовано як гіпотезу, у 2015 р. був організований і реалізований студентський дослідницький проект, спрямований на підтвердження або спростування цієї гіпотези. Базові методологія і методи дослідження були такими самими, як і в 2013-2014 рр. Однак тестування (дітей 5-6 років) і опитування (їх вихователів і батьків) проходили виключно у дошкільних навчальних закладах «інтенсивно розвиваючого» типу, таких, що використовують нетрадиційні освітні методики, які стимулюють і інтенсифікують когнітивний розвиток ( $\mathrm{n}=49)$. Слід зазначити, що дані, зібрані за допомогою методів спостереження (присутність на заняттях), інтерв'ю з педагогами і батьками вихованців цих закладів освіти, показали, що всі без виключення педагоги активно використовують індивідуальний підхід, а стиль їх спілкування з вихованцями на заняттях $є$, скоріше, партнерським, демократичним, таким, що базується на наданні якомога більшої свободи для творчого (креативного) прояву дітей. Адже встановлення саме таких стосунків $€$ необхідною умовою реалізації програм "розвиваючого навчання» та подібних.

Відповідно до нашої гіпотези, коефіцієнт кореляції між ступенем розвиненості когнітивного коду і професією матері вихованців «шкіл раннього розвитку» буде помітно нижчим, ніж аналогічний коефіцієнт у групі дітей, які є вихованцями звичайних дитячих садків (вибірка таких за результатами попереднього дослідження склала 45 осіб). Двовимірні розподіли показали, що коефіцієнти зв'язку між ступенем розвиненості когнітивних кодів і професією матері вихованців звичайних дитячих садків складають $\mathrm{T}=0,4 ; \mathrm{Tc}=0,4^{3}$, що свідчить про наявність помітного зв'язку. Аналіз даних 2015 р. показав значно нижчі коефіцієнти у групі вихованців «шкіл раннього розвитку» $-\mathrm{T}=0,15 ; \mathrm{Tc}=0,1$, що свідчить про наявність дуже слабкого зв'язку між ступеням розвиненості мовного і когнітивного коду

\section{Висновки.}

Отже отримані дані підтвердили нашу гіпотезу, як і ту, яку було сформульовано за результатами дослідження, проведеного на кафедрі соціології ХГУ «НУА» у 2013-2014 pp., а саме: ступінь розвиненості когнітивних кодів, хоча і залежить від фактору соціального походження, зокрема від роду занять матері як найважливішого агента первинної соціалізації, все ж таки стиль роботи педагога значною мірою впливає на розвиток когнітивних кодів. Дотримання вчителями демократичних засад спілкування і діалогічності освітнього дискурсу, спрямованість викладацьких методик, перш за все, на когнітивний розвиток учнів (а не на завантаження їх пам'яті інформацією) дозволить зняти один із фундаментальних бар'єрів нерівності в освіті, що закладається ще на перших освітніх сходинах - на рівні загальної дошкільної та початкової шкільної освіти.

На закінчення відзначимо, що орієнтиром освітньої політики держави має бути не боротьба 3 нерівністю, а управління нею. Причини та передумови відтворення соціальної нерівності через освіту криються в умовах і специфіці взаємодії учасників освітнього процесу. Для усунення «невидимих» бар'єрів, що існують в системі освіти і перешкоджають вертикальній соціальній мобільності, необхідною є модернізація змісту підготовки педагогічних кадрів.

\section{БІБІЛІОГРАФІЧНІ ПОСИЛАННЯ}

1. Бернстайн Б. Класс, коды и контроль: структура педагогического дискурса / Б. Бернстайн. - М.: Просвещение, 2008. - 272 с. 2. Бурдье П. Воспроизводство: элементы теории системы обра ᄀзования / П. Бурдье, Ж.-К. Пассерон. - М.: Просвещение, 2007. - $267 \mathrm{c}$.

3. Гидденс Е. Социология / Э. Гидденс. - М.: Эдиториал УРСС, 2005. - 632 с.

4. Нечитайло И. С. Возможности и перспективы применения некоторых ситуативных тестов в эмпирической социологии (на примере теста группировки картинок) / И. С. Нечитайло // Социс. - 2015. - № 6. - С. 68-77.

5. Нечитайло И. С. Изменение общества через изменение образования: иллюзия или реальность? / И. С. Нечитайло. Харьков: Изд-во НУА, 2015. - 552 с.

${ }^{2}$ Інституціоналізовані відносини - форма відносно стійких зв’язків і взаємодій, організованих відповідно до встановлених правил, норм, зразків поведінки, що підтримують (відображають, підкріплюють) існуючу ієрархію статусів і дисципліну.

${ }^{3}$ «Т» $\mathrm{i}$ «Тс» - коефіцієнти Чупрова і Крамера, відповідно, що показують силу зв'язку між ознаками. Чим ближче значення «Т» $\mathrm{i}$ «К» до 0, тим слабкіше зв’ язок. І навпаки, чим ближче «Т» $\mathrm{i}$ «К» до 1 , тим сильніше зв’язок. 
6. Нечітайло I. С. Системно-кодова концепція взаємодії суспільства та освіти: автореф. дис. д-ра соціол наук за спеціальністю 22.00.04 - спеціальні та галузеві соціології / І. С. Нечітайло. - Харків, 2018. - 40 с.

7. Оксамитна С. М. Освітня нерівність і експансія вищої освіти / С. М. Оксамитна // Приоритеты современного образования: теория, методология, практика: материалы международной научн.-практ. конф. - Харьков: Изд-во НУА, 2014. - С. 22-34.

8. Осипов А. М. Глобальная социология образования: зарубежный опыт решения социальных проблем в сфере образования / А. М. Осипова. - Великий Новгород: НовГУ, 2015. - 300 с.

9. Осипов А. М. Институциональные барьеры и механизмы доступности образования / А. Осипов, Н. Матвеева // Социс. - 2015. - № 7. - C. 37-48.

10. Apple M. W. The hidden curriculum and the nature of conflict / M. W. Apple // Interchange. - 1971. - № 2. - P. 27-40.

\section{REFERENCES}

1. Bernstajn, B. (2008). Klass, kody i kontrol': struktura pedagogicheskogo diskursa [Class, codes and control: the structure of pedagogical discourse]. Moscow: Prosveshchenie [in Russian].

2. Burd'e, P., \& Passeron, ZH.-K. (2007). Vosproizvodstvo: ehlementy teorii sistemy obrazovaniya [Reproduction: elements of the theory of the system of education]. Moscow: Prosveshchenie [in Russian].

3. Giddens, E. (2005). Sociologiya [Sociology]. Moscow: Editorial URSS [in Russian].

4. Nechitajlo, I.S. (2015). Vozmozhnosti i perspektivy primeneniya nekotoryh situativnyh testov v ehmpiricheskoj sociologii (na primere testa gruppirovki kartinok [Opportunities and prospects for the application of some situational tests in empirical sociology (on the example of a grouping test for pictures)]. Socis, 6, 68-77 [in Russian].

5. Nechitajlo, I.S. (2015). Izmenenie obshchestva cherez izmenenie obrazovaniya: illyuziya ili real'nost'? [The change of society through a change in education: illusion or reality?]. Kharkiv: Izd-vo NUA [in Russian].

6. Nechitajlo, I.S. (2018). Sistemno-kodova koncepciya vzajemodii suspil'stva ta osvity [System-code concept of the interaction of society and education]. Extended abstract of doctor's thesis. Kharkiv [in Ukrainian].

7. Oksamitna, S.M. (2014). Osvitnya nerivnist' i ekspansiya vishchoï osviti [Educational inequality and the expansion of higher education]. Prioritety sovremennogo obrazovaniya: teoriya, metodologiya, praktika - Priorities of Modern Education: Theory, Methodology, Practice: Proceedings from the International Scientific and Practical conference. Kharkiv: Izd-vo NUA [in Ukrainian].

8. Osipov, A.M. (2015). Global'naya sociologiya obrazovaniya [Global sociology of education: foreign experience in solving social problems in the sphere of education]. Velikij Novgorod: NovGU [in Russian].

9. Osipov, A.M., \& Matveeva, N.A. (2015) Institucional'nye bar'ery i mekhanizmy dostupnosti obrazovaniya: koncepciya i regional'naya dinamika [Institutional barriers and mechanisms of accessibility of education]. Socis, 7, $37-48$ [in Russian].

10. Apple, M.W. (1971) The hidden curriculum and the nature of conflict. Interchange, 2, 27-40.

\section{Нечітайло Ірина Сергіївна}

Доктор соціологічних наук, доцент, Завідувач кафедри соціології

Харківський гуманітарний університет «Народна українська академія»

61000, м. Харків, вул. Лермонтовська, 27

\section{Nechitaylo Iryna}

Doctor of Sociology, Associate Professor, Head of the Department of Sociology

Kharkov University of Humanities «Peoples Ukrainian Academy»

27, Lermontovska str., Kharkiv, 61000, Ukraine

Email: nechit@ukr.net

ORCID: 0000-0002-0656-0370

\section{Минко Аліса Віталіївна}

Магістр соціології

Харківський гуманітарний університет «Народна українська академія»

61000, м. Харків, вул. Лермонтовська, 27

\section{Minko Alisa}

Master of Sociology

Kharkov University of Humanities «Peoples Ukrainian Academy»

27, Lermontovska str., Kharkiv, 61000, Ukraine

Email: aliceminka@gmail.com

Цитування: Нечітайло І. С. «Невидимі» бар’єри соціальної нерівності: передумови відтворення у дошкільній і початковій освіті / І. С. Нечітайло, А. В. Мінко // Науково-теоретичний альманах «Грані». - 2018. - Т. 21. - № 9. - С. 41-46.

Citation: Nechitailo, I.S., Minko, A.V. (2018). «Nevydymi» bariery sotsialnoi nerivnosti: peredumovy vidtvorennia u doshkilnii i pochatkovii osviti [ «Invisible» barriers to social inequality: the preconditions for reproduction in preschool and primary education]. Scientific and theoretical almanac "Grani», 21(9), 41-46. 